\title{
Previous Ethanol Experience Enhances Synaptic Plasticity of NMDA Receptors in the Ventral Tegmental Area
}

\author{
Brian E. Bernier, Leslie R. Whitaker, and Hitoshi Morikawa \\ Waggoner Center for Alcohol and Addiction Research, Section of Neurobiology and Institute for Neuroscience, University of Texas at Austin, Austin, Texas \\ 78712
}

Alcohol addiction (alcoholism) is one of the most prevalent substance abuse disorders worldwide. Addiction is thought to arise, in part, from a maladaptive learning process in which enduring memories of drug experiences are formed. However, alcohol (ethanol) generally interferes with synaptic plasticity mechanisms in the CNS and thus impairs various types of learning and memory. Therefore, it is unclear how powerful memories associated with alcohol experience are formed during the development of alcoholism. Here, using brain slice electrophysiology in mice, we show that repeated in vivo ethanol exposure $(2 \mathrm{~g} / \mathrm{kg}$, i.p., three times daily for $7 \mathrm{~d})$ causes increased susceptibility to the induction of long-term potentiation (LTP) of NMDA receptor (NMDAR)-mediated transmission in mesolimbic dopamine neurons, a form of synaptic plasticity that may drive the learning of stimuli associated with rewards, including drugs of abuse. Enhancement of NMDAR plasticity results from an increase in the potency of inositol 1,4,5-trisphosphate (IP $\left.{ }_{3}\right)$ in producing facilitation of action potential-evoked $\mathrm{Ca}^{2+}$ signals, which is critical for LTP induction. This increase in IP ${ }_{3}$ effect, which lasts for a week but not a month after ethanol withdrawal, occurs through a protein kinase A (PKA)-dependent mechanism. Corticotropin-releasing factor, a stress-related neuropeptide implicated in alcoholism and other addictions, further amplifies the PKA-mediated increase in $\mathrm{IP}_{3}$ effect in ethanol-treated mice. Finally, we found that ethanol-treated mice display enhanced place conditioning induced by the psychostimulant cocaine. These data suggest that repeated ethanol experience may promote the formation of drug-associated memories by enhancing synaptic plasticity of NMDARs in dopamine neurons.

\section{Introduction}

Despite the large impact of alcohol abuse on society, the neural mechanisms underlying the development of alcoholism, i.e., alcohol addiction, are not well understood. Development of addiction involves a maladaptive form of learning and memory in which drug-related experiences are remembered powerfully, resulting in persistent and uncontrollable drug seeking behavior (Hyman et al., 2006). However, it is well known that alcohol (ethanol) intoxication impairs various types of learning and memory in both humans and animals. Decreases in learning capacity have also been reported in long-term alcoholics and in animals withdrawn from repeated ethanol exposure (Ryback, 1971; Ryabinin, 1998; Stephens et al., 2005). In line with these observations, both acute and chronic exposures to ethanol have been shown to suppress activity-dependent synaptic plasticity, the major neural substrate for learning and memory, in various brain areas (Stephens et al., 2005; Belmeguenai et al., 2008; Xie et al., 2009).

The mesolimbic dopaminergic system that originates in the ventral tegmental area (VTA) is critically involved in the learning

Received Oct. 7, 2010; revised Feb. 4, 2011; accepted Feb. 14, 2011.

Author contributions: B.E.B. and H.M. designed research; B.E.B. and L.W. performed research;B.E.B., L.R.W., and H.M. analyzed data; and B.E.B. and H.M. wrote the paper.

This work was supported by National Institutes of Health Grant AA015521. B.E.B. was supported by a National Research Service Award.

Correspondence should be addressed to Hitoshi Morikawa, Section of Neurobiology, University of Texas at Austin, 2400 Speedway, PAT 402, Austin, TX 78712. E-mail: morikawa@mail.utexas.edu.

DOI:10.1523/JNEUROSCI.5282-10.2011

Copyright $\odot 2011$ the authors $\quad 0270-6474 / 11 / 315205-08 \$ 15.00 / 0$ of information related to rewards, including drugs of abuse (Schultz, 1998; Hyman et al., 2006). Both natural rewards and drug rewards, such as ethanol, cause release of dopamine in the nucleus accumbens and other limbic structures, which is thought to drive learning by enhancing synaptic plasticity. However, ethanol intoxication may suppress reward-based conditioning (Busse et al., 2004; Cunningham and Gremel, 2006), presumably by hampering synaptic plasticity in dopamine projection areas (Xie et al., 2009). Accumulating evidence indicates that plasticity of glutamatergic transmission onto dopamine neurons within the VTA may also play important roles in the development of drug addiction (Hyman et al., 2006; Kauer and Malenka, 2007). Consistent with this idea, in vivo exposure to ethanol has been shown to produce global enhancement of AMPA receptor (AMPAR)-mediated transmission in VTA dopamine neurons (Saal et al., 2003; Stuber et al., 2008). However, it is not clear whether ethanol experience can promote activity-dependent plasticity of glutamatergic synapses in the VTA.

Plasticity of NMDA receptor (NMDAR)-mediated transmission may be of particular interest, as NMDAR activation in the VTA is necessary for dopamine neuron burst firing and phasic dopamine release in projection areas that occurs in response to rewards or reward-predicting stimuli (Sombers et al., 2009; Zweifel et al., 2009). We have recently reported long-term potentiation (LTP) of NMDAR EPSCs that is induced by sustained glutamatergic input activity paired with postsynaptic burst firing (Harnett et al., 2009). LTP induction requires amplification of action potential (AP)-evoked $\mathrm{Ca}^{2+}$ signals by preceding activa- 
tion of metabotropic glutamate receptors (mGluRs). This amplification is dependent on $\mathrm{Ca}^{2+}$ release from intracellular stores, where inositol 1,4,5-trisphosphate $\left(\mathrm{IP}_{3}\right)$ generated by mGluR activation increases $\mathrm{Ca}^{2+}$-induced $\mathrm{Ca}^{2+}$ release triggered by APinduced $\mathrm{Ca}^{2+}$ influx (Cui et al., 2007).

Long-term ethanol treatment has been shown to produce an enhancement of $\mathrm{IP}_{3}$-mediated $\mathrm{Ca}^{2+}$ signaling in different cell types (Nomura et al., 1996; Saso et al., 1997; Netzeband et al., 2002). In the present study, we examined whether repeated in vivo ethanol exposure promotes $\mathrm{mGluR} / \mathrm{IP}_{3}$-dependent plasticity of NMDAR EPSCs in VTA dopamine neurons.

\section{Materials and Methods}

Animals. Male C57BL/6J mice (3-8 weeks old) were obtained from Jackson Laboratory and were housed under a $12 \mathrm{~h}$ light/dark cycle (lights on at 7:00 A.M.). Food and water were available ad libitum. All animal procedures were approved by the University of Texas Institutional Animal Care and Use Committee.

In vivo ethanol treatment. Mice (3-4 weeks old) received intraperitoneal injections of ethanol $(2 \mathrm{~g} / \mathrm{kg}, 20 \% \mathrm{v} / \mathrm{v})$ or an equivalent volume of saline, 3 times per day (3-3.5 h apart) for $7 \mathrm{~d}(6 \mathrm{~g} / \mathrm{kg}$ ethanol per day). Mice were returned to the home cage immediately after each injection. It has been shown that intraperitoneal injection of $2 \mathrm{~g} / \mathrm{kg}$ ethanol produces blood ethanol levels of $\sim 1.8 \mathrm{mg} / \mathrm{ml}$ in C57BL/6J mice (Crabbe et al., 2003), which are comparable to the levels achieved during ethanol drinking $(\sim 1.6 \mathrm{mg} / \mathrm{ml})$ (Elmer et al., 1987; Rhodes et al., 2005). It should also be noted that male C57BL/6J mice consume $\sim 10-14 \mathrm{~g} / \mathrm{kg}$ ethanol per day during continuous-access two-bottle choice drinking (Blednov et al., 2005).

Electrophysiology. Mice were killed by cervical dislocation under halothane or isoflurane anesthesia, and horizontal midbrain slices (190-210 $\mu \mathrm{m}$ ) containing the VTA were cut in an ice-cold solution containing (in mM): 205 sucrose, $2.5 \mathrm{KCl}, 1.25 \mathrm{NaH}_{2} \mathrm{PO}_{4}, 7.5 \mathrm{MgCl}_{2}, 0.5 \mathrm{CaCl}_{2}, 10$ glucose, and $25 \mathrm{NaHCO}_{3}$, saturated with $95 \% \mathrm{O}_{2}$ and $5 \% \mathrm{CO}_{2}(\sim 305$ $\mathrm{mOsm} / \mathrm{kg}$ ) and incubated $>1 \mathrm{~h}$ at $35^{\circ} \mathrm{C}$ in a solution containing (in $\mathrm{mm}$ ): $126 \mathrm{NaCl}, 2.5 \mathrm{KCl}, 1.2 \mathrm{NaH}_{2} \mathrm{PO}_{4}, 1.2 \mathrm{MgCl}_{2}, 2.4 \mathrm{CaCl}_{2}, 11$ glucose, and $25 \mathrm{NaHCO}_{3}$, saturated with $95 \% \mathrm{O}_{2}$ and $5 \% \mathrm{CO}_{2}$ (pH 7.4, $295 \mathrm{mOsm} /$ $\mathrm{kg}$ ). Recordings were made at $34-35^{\circ} \mathrm{C}$ in the same solution perfused at $\sim 2.5 \mathrm{ml} / \mathrm{min}$. The pipette solution contained (in $\mathrm{mM}$ ) 115 K-methylsulfate, $20 \mathrm{KCl}, 1.5 \mathrm{MgCl}_{2}$, 10 HEPES, 0.025 EGTA, $2 \mathrm{Mg}$-ATP, 0.2 $\mathrm{Na}_{2}$-GTP, and $10 \mathrm{Na}_{2}$-phosphocreatine ( $\mathrm{pH} 7.25, \sim 280 \mathrm{mOsm} / \mathrm{kg}$ ).

Cells were visualized using an upright microscope (Olympus) with infrared/differential interference contrast optics. Recordings were made in the lateral VTA located between 50 and $150 \mu \mathrm{m}$ from the medial border of the medial terminal nucleus of the accessory optic tract. Putative dopamine neurons were identified by their spontaneous firing (1-5 $\mathrm{Hz}$ ) with broad APs $(>1.2 \mathrm{~ms})$ recorded in cell-attached configuration and large $I_{\mathrm{h}}$ currents $(>200 \mathrm{pA}$ elicited by $1.5 \mathrm{~s}$ hyperpolarizing steps from $-62 \mathrm{mV}$ to $-112 \mathrm{mV}$ ) in whole-cell configuration. Whole-cell voltage-clamp recordings were made at a holding potential of $-62 \mathrm{mV}$, corrected for a liquid junction potential of $-7 \mathrm{mV}$. Pipettes with tip resistance of 1.5-2.0 M $\Omega$ were used. Series and input resistances were monitored throughout experiments and recordings were discarded if the series resistance increased beyond $20 \mathrm{M} \Omega$ or the input resistance dropped below $200 \mathrm{M} \Omega$. A Multiclamp 700A amplifier (Molecular Devices) and AxoGraph X (AxoGraph Scientific) were used to record and collect data, which were filtered at $1-5 \mathrm{kHz}$ and digitized at $2-10 \mathrm{kHz}$.

Unclamped APs were evoked with 2 ms depolarizing pulses from -62 $\mathrm{mV}$ to $-7 \mathrm{mV}$. The time integral of the outward tail current, termed $I_{\mathrm{K}(\mathrm{Ca})}$, was calculated after removing a $20 \mathrm{~ms}$ window following the depolarizing pulse (expressed in picocoulombs). We have shown previously that $I_{\mathrm{K}(\mathrm{Ca})}$ thus measured is completely eliminated by TTX and also by apamin, a selective blocker of small-conductance $\mathrm{Ca}^{2+}$-sensitive $\mathrm{K}^{+}$ (SK) channels, and hence can be used as a readout of AP-induced $\mathrm{Ca}^{2+}$ transients (Cui et al., 2007).

Flash photolysis. Caged $\mathrm{IP}_{3}$ (25 or $200 \mu \mathrm{M}$; Invitrogen) was loaded into the cytosol through the whole-cell pipette. A $1 \mathrm{~ms}$ UV pulse was applied using a xenon arc lamp (Cairn Research) to rapidly release $\mathrm{IP}_{3}$. The UV pulse was focused through a $60 \times$ objective onto an $\sim 350-\mu$ m-diameter area centered at recorded neurons. The amount of photolysis is known to be proportional to the UV pulse intensity (McCray et al., 1980), which is proportional to the capacitance of the capacitor feeding current to the flash lamp. UV pulse intensity is therefore reported in units of capacitance $(50-4050 \mu \mathrm{F})$.

LTP experiments. Synaptic stimuli were applied every $20 \mathrm{~s}$ using bipolar tungsten electrodes $(\sim 100 \mu \mathrm{m}$ tip separation) placed $50-150 \mu \mathrm{m}$ rostral to the recorded neuron. To isolate NMDAR EPSCs, recordings were performed in the presence of DNQX $(10 \mu \mathrm{M})$, picrotoxin $(100 \mu \mathrm{M})$, and eticlopride (100 nM) to block AMPA, GABA $A_{A}$, and $D_{2}$ dopamine receptors. For LTP induction, sustained synaptic stimulation (70 stimuli at $50 \mathrm{~Hz}$ ) was paired with a burst of $5 \mathrm{APs}$ at $20 \mathrm{~Hz}$, with the burst onset delayed $1 \mathrm{~s}$ from the onset of the synaptic stimulation train. This synaptic stimulation-burst pairing was repeated 10 times every 20 s. Magnitude of LTP was determined by comparing the average EPSC amplitude over the $10 \mathrm{~min}$ baseline period with that during another $10 \mathrm{~min}$ window $\sim 30-40$ min after LTP induction.

Conditioned place preference. A conditioned place preference (CPP) box consisting of two distinct compartments, separated by a small middle chamber, was used for conditioning (Med Associates). One compartment had a mesh floor with white walls, while the other had a grid floor with black walls. One day after the $7 \mathrm{~d}$ saline/ethanol treatment in the home cage, mice were subjected to a pretest in a conditioning room, in which they were allowed to freely explore the entire CPP box for $20 \mathrm{~min}$. The percentage of time spent in each compartment was determined after excluding the time spent in the middle chamber. Any mice that spent $>60 \%$ of time in either compartment during the pretest were not used for conditioning. For cocaine CPP, mice were subjected to $2 \mathrm{~d}$ conditioning starting the next day, in which one of the two compartments was randomly assigned as the cocaine-paired side in each mouse. Here, mice were given an injection of cocaine ( $5 \mathrm{mg} / \mathrm{kg}$, i.p.) and confined to one compartment for $30 \mathrm{~min}$ in one trial and given a saline injection and confined to the other compartment for $30 \mathrm{~min}$ in another trial. The two trials were separated by at least $4 \mathrm{~h}$. The order of cocaine/saline trials was reversed on the second day of conditioning. A 20 min posttest was performed the following day. Mice that spent $>8 \mathrm{~min}$ in the middle chamber during pretest or posttest were excluded from analysis. CPP score was determined by subtracting the preference for the cocaine-paired side in the pretest from that in the posttest. For ethanol CPP, mice were subjected to $4 \mathrm{~d}$ conditioning in which they were given either ethanol $(2 \mathrm{~g} / \mathrm{kg}$, i.p.) or saline and confined to one compartment for $5 \mathrm{~min}$.

Drugs. 3,4-Dihydroxyphenylglycol (DHPG), CRF, DNQX, eticlopride, and K41498 were obtained from Tocris Bioscience. Caged $\mathrm{IP}_{3}$ was purchased from Invitrogen. All other chemicals were from Sigma-RBI.

Data analysis. Data are expressed as mean \pm SEM. Statistical significance was determined by Student's $t$ test or ANOVA followed by Bonferroni post hoc test. The difference was considered significant at $p<0.05$.

\section{Results}

In vivo ethanol experience leads to enhanced mGluR-mediated facilitation of AP-evoked $\mathrm{Ca}^{2+}$ signals and increased $\mathrm{IP}_{3}$ sensitivity

$\mathrm{mGluR} / \mathrm{IP}_{3}$-induced facilitation of AP-evoked $\mathrm{Ca}^{2+}$ signals is required for the induction of NMDAR LTP in dopamine neurons (Harnett et al., 2009). Thus, we first tested whether in vivo ethanol exposure alters the effect of the mGluR agonist DHPG on APevoked $\mathrm{Ca}^{2+}$ signals, which were assessed by measuring SK currents $\left(I_{\mathrm{K}(\mathrm{Ca})}\right)$ following unclamped APs evoked by brief depolarizing pulses (see Materials and Methods). Recordings were made in midbrain slices prepared from naive C57BL/6J mice and mice that received injections of saline or ethanol (2 $\mathrm{g} / \mathrm{kg}$, i.p.) 3 times daily for $7 \mathrm{~d}$ ( $4-5$ weeks old at the time of slice preparation). Bath perfusion of DHPG $(3 \mu \mathrm{M})$ produced small facilitation of $I_{\mathrm{K}(\mathrm{Ca})}$ in VTA dopamine neurons from naive or saline-treated mice (Fig. 1 $A, B$ ). This DHPG effect was significantly increased $1 \mathrm{~d}$ after withdrawal from $7 \mathrm{~d}$ ethanol treatment. 


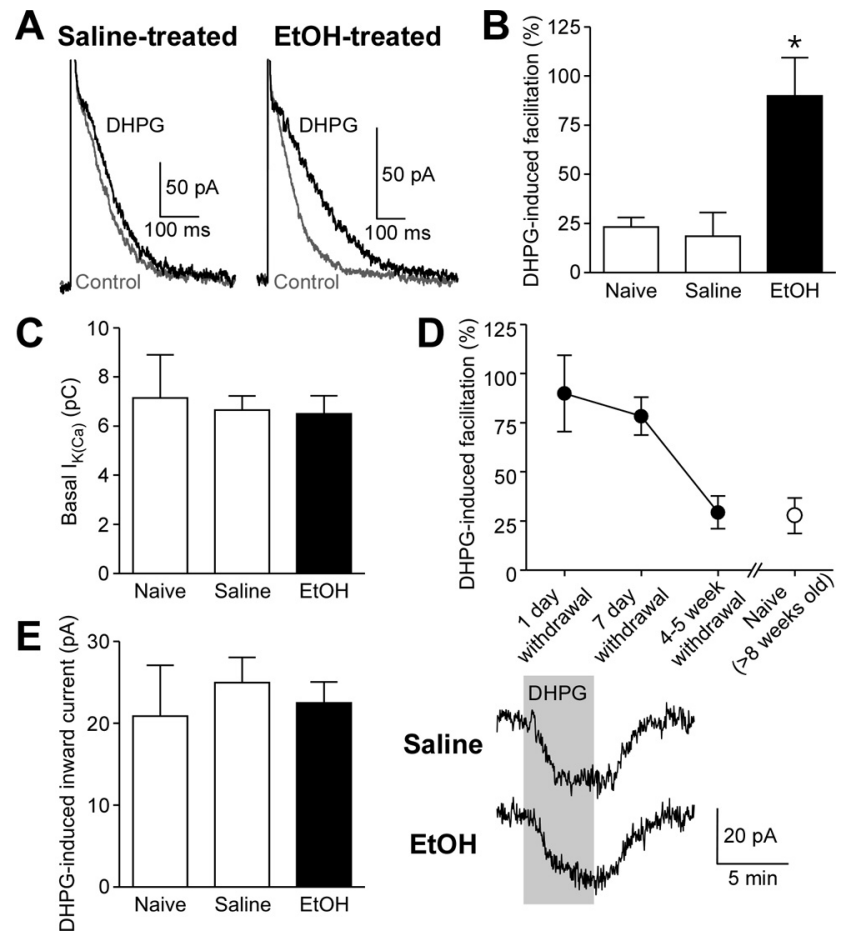

Figure 1. mGluR-dependent facilitation of AP-evoked $\mathrm{Ca}^{2+}$ signals is augmented after withdrawal from repeated ethanol exposure. $A$, Example traces of $I_{K(C)}$ illustrating the effects of DHPG $(3 \mu \mathrm{m})$ on $I_{K(\mathrm{Ca})}$ in cells from saline- and ethanol-treated mice (1 d withdrawal). $\boldsymbol{B}$, Summary bar graph demonstrating that in vivo ethanol exposure augmented DHPG-induced facilitation of $I_{\mathrm{K}(\mathrm{Ca})}$ (naive group, 7 cells from 4 mice; saline group, 10 cells from 5 mice; ethanol group, 14 cells from 8 mice; $F_{(2,28)}=6.25, p<0.01$, one-way ANOVA). ${ }^{*} p<0.05$ versus naive and saline groups. $C$, The size of basal $I_{\mathrm{K}(\mathrm{Ca})}$ was not altered after ethanol treatment. $\boldsymbol{D}$, Summary graph depicting DHPG effect on $I_{\mathrm{K}(\mathrm{Ca})}$ after different periods of ethanol withdrawal $11 \mathrm{~d}$ withdrawal group, 14 cells from 8 mice; $7 \mathrm{~d}$ withdrawal group, 7 cells from 5 mice; 4-5 week withdrawal group, 10 cells from 5 mice; naive ( $>8$ weeks old) group, 9 cells from 5 mice]. $\boldsymbol{E}$, DHPG-induced inward currents were not affected by ethanol treatment. Right, Example traces of DHPG-induced currents in cells from saline- and ethanol-treated mice. DHPG was perfused at the time indicated. The data in $\boldsymbol{C}$ and $\boldsymbol{E}$ were obtained from the same cells shown in $\boldsymbol{B}$.

There was no change in the basal $I_{\mathrm{K}(\mathrm{Ca})}$ amplitude (Fig. 1C). DHPG effect on $I_{\mathrm{K}(\mathrm{Ca})}$ was still elevated $7 \mathrm{~d}$ after cessation of ethanol exposure, however it returned to a level comparable to that of the age-matched naive control (8-9 weeks old) after 4-5 weeks of withdrawal (Fig. 1D). Subsequent data for saline- and ethanol-treated mice in the present study were obtained $1 \mathrm{~d}$ after $7 \mathrm{~d}$ saline/ethanol exposure. DHPG-induced inward currents, which are independent of $\mathrm{IP}_{3}$ or $\mathrm{Ca}^{2+}$ (Guatteo et al., 1999; Cui et al., 2007) and likely involve activation of transient receptor potential-like channels (Tozzi et al., 2003), were not altered by ethanol treatment (Fig. 1E), suggesting that the increase in DHPG effect on $I_{\mathrm{K}(\mathrm{Ca})}$ results from changes in $\mathrm{IP}_{3}$ signaling downstream of mGluRs.

To more directly examine the alterations in $\mathrm{IP}_{3}$ signaling, we next performed flash photolysis of caged $\mathrm{IP}_{3}(200 \mu \mathrm{M})$ and measured the resulting SK-mediated outward current $\left(I_{\mathrm{IP} 3}\right)$ (Morikawa et al., 2000). The concentration of $\mathrm{IP}_{3}$ released was varied by applying different UV flash intensities, which were determined by the capacitance (up to $4050 \mu \mathrm{F}$ ) of the capacitor in the photolysis system (see Materials and Methods). $\mathrm{IP}_{3}$ concentration-response curves thus constructed exhibited a leftward shift after in vivo ethanol exposure (Fig. $2 A, B$ ). The average $\mathrm{EC}_{50}$ value [i.e., the UV intensity (expressed in microfarads) producing half-maximal current] was significantly lower in ethanol-
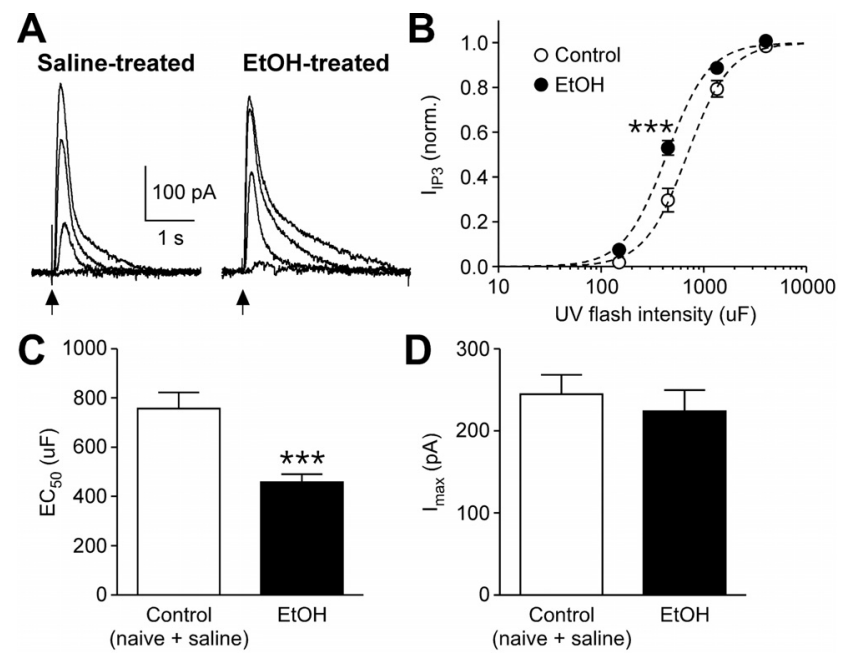

Figure 2. In vivo ethanol exposure increases $\mathbb{I P}_{3}$ sensitivity. $A$, Traces of $I_{\mathrm{P} 3}$ evoked with different UV pulse intensities $(150,450,1350$, and $4050 \mu \mathrm{F})$ in VTA neurons from saline- and ethanol-treated mice. These cells were loaded with caged IP $(200 \mu \mathrm{M})$. UV flashes were applied at the time indicated by the arrow. $\boldsymbol{B}$, Averaged concentration (UV flash intensity)-response $\left(I_{\mathrm{IP3}}\right)$ curves from control and ethanol-treated mice. The $I_{\mathrm{IP3}}$ amplitude was normalized to the maximal value (estimated from fit to a logistic equation) in each cell. Data from naive and saline-treated mice were pooled as a control group (control group, 13 cells from 7 naive mice and 6 cells from 4 saline-treated mice; ethanol group, 16 cells from 10 mice; group, $F_{(1,99)}=$ $12.7, p<0.01$; flash intensity, $F_{(3,99)}=643.1, p<0.0001$; group $\times$ flash intensity, $F_{(3,99)}=$ $7.45, p<0.001$, mixed two-way ANOVA). Dashed lines are fit to a logistic equation. ${ }^{* * *} p<$ 0.001 versus control. $C$, Summary bar graph showing that $\mathrm{EC}_{50}$ values were reduced in ethanoltreated mice $\left(t_{33}=3.88, p<0.001\right.$, unpaired $t$ test $)$. $\boldsymbol{D}$, The maximal $I_{\mathrm{IP} 3}$ amplitude was not altered by in vivo ethanol treatment.

treated mice compared with controls (Fig. 2C), while there was no difference in the maximal $I_{\mathrm{IP} 3}$ amplitude (Fig. $2 D$ ). Therefore, repeated ethanol exposure increases $\mathrm{IP}_{3}$ sensitivity in VTA dopamine neurons.

\section{Repeated ethanol exposure and acute CRF application both enhance $\mathrm{IP}_{3}$ signaling via protein kinase $\mathrm{A}$}

It has been shown that in vivo ethanol exposure causes upregulation of the adenylyl cyclase-cAMP-PKA (protein kinase A) pathway in the mesolimbic dopamine system (Ortiz et al., 1995; Melis et al., 2002). PKA-mediated phosphorylation of $\mathrm{IP}_{3}$ receptors $\left(\mathrm{IP}_{3} \mathrm{Rs}\right)$ increases their $\mathrm{IP}_{3}$ sensitivity (Wagner et al., 2008). Thus, we tested the effect of forskolin, a potent activator of adenylyl cyclase, on $I_{\mathrm{IP} 3}$ in naive mice. Bath perfusion of forskolin $(3 \mu \mathrm{M})$ caused a significant increase in $I_{\mathrm{IP} 3}$ evoked with an $\mathrm{EC}_{50}$ flash intensity, while there was minimal enhancement of $I_{\mathrm{IP} 3}$ evoked with a maximal flash intensity (Fig. $3 A, B$ ). Therefore, activation of the cAMP-PKA pathway increases $\mathrm{IP}_{3} \mathrm{R}$ sensitivity in a manner analogous to repeated ethanol exposure. We further tested forskolin $(3-10 \mu \mathrm{M})$ on AP-evoked $I_{\mathrm{K}(\mathrm{Ca})}$ and found that it had no effect (Fig. 3C,D), similarly to the lack of effect of in vivo ethanol treatment on $I_{\mathrm{K}(\mathrm{Ca})}$ (Fig. 1C).

Repeated ethanol exposure increases CRF levels in the brain (Sarnyai et al., 2001; Heilig and Koob, 2007). Furthermore, it has been shown that activation of $\mathrm{CRF}_{2}$ receptors potentiates mGluR-induced intracellular $\mathrm{Ca}^{2+}$ release via a PKA-dependent mechanism in dopamine neurons (Riegel and Williams, 2008). Therefore, we next examined the effects of $\mathrm{CRF}$ on $\mathrm{IP}_{3}$ signaling in saline- and ethanol-treated mice. In these experiments, dopamine neurons were filled with a low concentration of caged $\mathrm{IP}_{3}$ $(25 \mu \mathrm{M})$ and subjected to a subthreshold UV flash $(100 \mu \mathrm{F})$ that produced no measurable outward current by itself. This sub- 


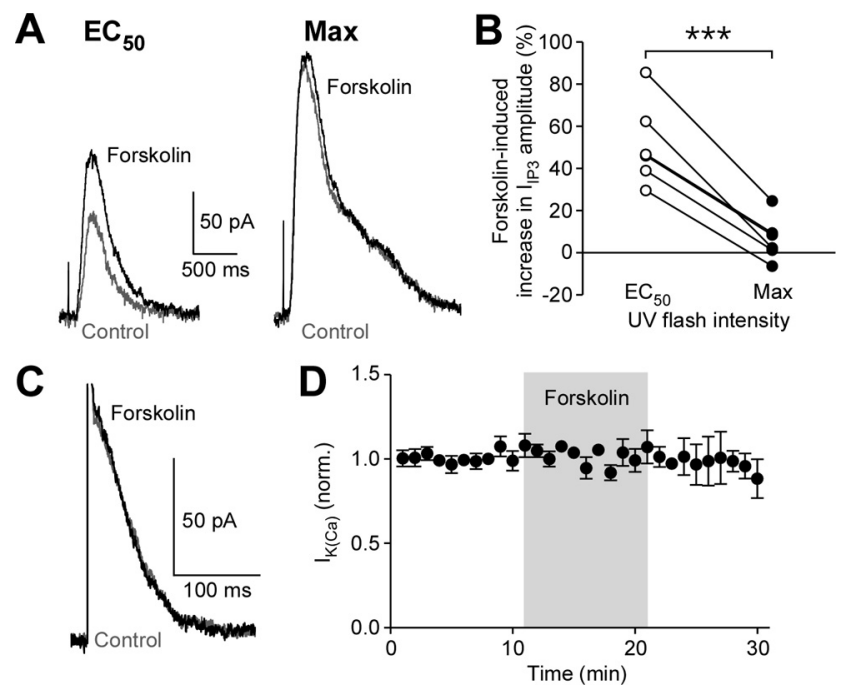

Figure 3. Stimulation of the cAMP-PKA pathway increases $\mathbb{P}_{3}$ sensitivity. $A$, Representative traces of $I_{I P 3}$ in control (gray) and forskolin ( $3 \mu \mathrm{m}$; black). Traces on the left were elicited with an $\mathrm{EC}_{50}$ flash intensity, while those on the right represent maximal $I_{\mid \mathrm{P} 3}$ evoked in the same cell. The cell was loaded with caged $\mathrm{IP}_{3}(200 \mu \mathrm{M})$. B Effects of forskolin on $I_{\mathrm{PB}}$ evoked with $\mathrm{EC}_{50}$ or maximal flash intensities are plotted in 6 cells $\left(t_{5}=9.07, p<0.001\right.$, paired $t$ test). $C$, Example traces of $I_{K(C a)}$ in control (gray) and forskolin ( $10 \mu \mathrm{M}$; black). $\boldsymbol{D}$, Summary time graph demonstrating that forskolin $(3-10 \mu \mathrm{M})$ failed to affect $I_{\mathrm{K}(\mathrm{Ca})}(n=5)$.

threshold flash caused significant facilitation of $I_{\mathrm{K}(\mathrm{Ca})}$ when applied $50 \mathrm{~ms}$ before an AP (Fig. 4A). The flash intensity was held constant to compare the magnitude of $I_{\mathrm{K}(\mathrm{Ca})}$ facilitation caused by the same concentration of $\mathrm{IP}_{3}$ in different cells. In salinetreated animals, bath perfusion of CRF (300 nM) significantly increased the magnitude of $\mathrm{IP}_{3}$-induced facilitation of $I_{\mathrm{K}(\mathrm{Ca})}$ (Fig. $4 A, C$ ). Consistent with the results from DHPG experiments (Fig. $1 \mathrm{~B}), \mathrm{IP}_{3}$-induced facilitation of $I_{\mathrm{K}(\mathrm{Ca})}$ was significantly larger in ethanol-treated mice compared with saline-treated controls (Fig. $4 A-C)$. Furthermore, CRF was able to cause a robust additional increase in $I_{\mathrm{K}(\mathrm{Ca})}$ that was already greatly facilitated by $\mathrm{IP}_{3}$ in ethanol-treated mice. Treatment with the PKA inhibitor H89 (10 $\mu \mathrm{M},>1 \mathrm{~h}$ preincubation plus intracellular application through whole-cell pipette) reversed the increase in $I_{\mathrm{K}(\mathrm{Ca})}$ facilitation following in vivo ethanol exposure and also completely abolished the effect of CRF. Notably, CRF application or H89 treatment had no effect on basal $I_{\mathrm{K}(\mathrm{Ca})}$ not facilitated by $\mathrm{IP}_{3}$ (Fig. $4 D$; also note the overlap of gray and orange traces in Fig. $4 A, B$ ). We further confirmed that the augmentation of $\mathrm{IP}_{3}$ effect by CRF was suppressed by prior application of the selective $\mathrm{CRF}_{2}$ receptor antagonist K41498 (100-300 nM) in ethanol-treated mice (Fig. 4E). K41498 itself had no effect on $\mathrm{IP}_{3}$-induced facilitation of $I_{\mathrm{K}(\mathrm{Ca})}$, showing the absence of functional CRF tone in brain slices. Together, these data demonstrate that previous in vivo ethanol exposure and acute CRF application converge on PKA to amplify the facilitatory effect of $\mathrm{IP}_{3}$ on $\mathrm{AP}$-evoked $\mathrm{Ca}^{2+}$ signals.

In vivo ethanol experience promotes NMDAR plasticity We next examined whether repeated ethanol exposure affects the

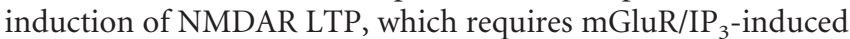
$\mathrm{Ca}^{2+}$ signal facilitation and is gated by PKA activity (Harnett et al., 2009). Pharmacologically isolated NMDAR EPSCs were recorded at $-62 \mathrm{mV}$ in physiological $\mathrm{Mg}^{2+}(1.2 \mathrm{~mm})$ solution (see Materials and Methods). Previous studies using C57BL/6J mice have found no global changes in NMDAR function in VTA dopamine neurons after repeated in vivo injections of ethanol (Bro- die, 2002; Hopf et al., 2007). Therefore, we normalized synaptic stimulation intensity using the NMDAR EPSC amplitude ( $\sim 20-30 \mathrm{pA}$; saline group: $26 \pm 2 \mathrm{pA}, 8$ cells from 7 mice; ethanol group: $27 \pm 3$ pA, 5 cells from 5 mice). Following $10 \mathrm{~min}$ baseline recording, LTP was induced by repetitively pairing (10 times every $20 \mathrm{~s}$ ) sustained synaptic stimulation $(70$ stimuli at $50 \mathrm{~Hz})$ with a burst of 5 APs at $20 \mathrm{~Hz}$ in the postsynaptic neuron. While this pairing protocol resulted in relatively small LTP of NMDAR EPSCs in saline-treated controls, ethanol-treated animals exhibited significantly larger magnitude of LTP (Fig. 5A-C). Before running the LTP induction protocol, facilitation of $I_{\mathrm{K}(\mathrm{Ca})}$ by synaptic stimulation was assessed in each neuron by evoking an AP at $60 \mathrm{~ms}$ after the end of a $1 \mathrm{~s}$ stimulation train. We found that facilitation of $I_{\mathrm{K}(\mathrm{Ca})}$ by synaptic stimulation was significantly increased in neurons from ethanol-treated animals (Fig. 5D). Furthermore, the magnitude of NMDAR LTP was positively correlated with that of $I_{\mathrm{K}(\mathrm{Ca})}$ facilitation across neurons from both groups of mice $(r=0.61, p<0.05)$ (Fig. $5 E)$. These data demonstrate that repeated ethanol exposure enhances the induction of NMDAR plasticity, most likely via an increase in mGluRmediated facilitation of AP-evoked $\mathrm{Ca}^{2+}$ signals.

\section{Previous ethanol experience enhances subsequent cocaine-induced place conditioning}

Enhanced NMDAR plasticity in VTA dopamine neurons may facilitate the learning of environmental stimuli associated with rewards, including drugs of abuse (Ahn et al., 2010). Thus, we tested the effect of repeated ethanol exposure on subsequent reward learning using cocaine-induced CPP, a form of behavioral conditioning that is dependent on NMDARs in the VTA (Harris et al., 2004; Zweifel et al., 2008). Mice were first treated with either saline or ethanol ( $2 \mathrm{~g} / \mathrm{kg}$, i.p.) for $7 \mathrm{~d}$, as described above. Then, after initial preference for the two compartments of the CPP box was determined on the pretest day, mice were subjected to $2 \mathrm{~d}$ conditioning in which cocaine $(5 \mathrm{mg} / \mathrm{kg}$, i.p.) was paired with one compartment while saline was paired with the other compartment on each day. During the CPP posttest, ethanoltreated mice exhibited a significantly greater increase in preference for the cocaine-paired compartment (Fig. 6A, B). These data demonstrate that repeated ethanol exposure enhances subsequent learning of cocaine-associated environmental stimuli.

We further asked whether repeated ethanol exposure could affect subsequent ethanol CPP. To test this, mice underwent $4 \mathrm{~d}$ CPP conditioning with ethanol (2 g/kg, i.p.) after $7 \mathrm{~d}$ saline/ ethanol treatment. Neither group developed significant preference for the ethanol-paired compartment (Fig. 6C,D), in agreement with a previous report showing that C57BL/6J mice do not readily develop ethanol CPP (Cunningham et al., 1992).

\section{Discussion}

It is well known that acute ethanol exposure inhibits NMDAR function, thus causing suppression of many forms of synaptic plasticity that are dependent on NMDAR activation in the CNS (Lovinger et al., 1989; Ron, 2004). In contrast, long-term ethanol exposure has been shown to produce upregulation of NMDAR function/expression in the hippocampus (Nelson et al., 2005), amygdala (Roberto et al., 2006), and striatum (Wang et al., 2010), although it is not clear whether this leads to an enhancement of NMDAR-dependent synaptic plasticity (Stephens et al., 2005; Xia et al., 2006; Sabeti and Gruol, 2008). In the present study, we found that VTA dopamine neurons exhibit increased susceptibility to the induction of $\mathrm{mGluR} / \mathrm{IP}_{3}$-dependent LTP of NMDAR EPSCs after repeated ethanol exposure in vivo. Our finding pro- 
A Saline-treated

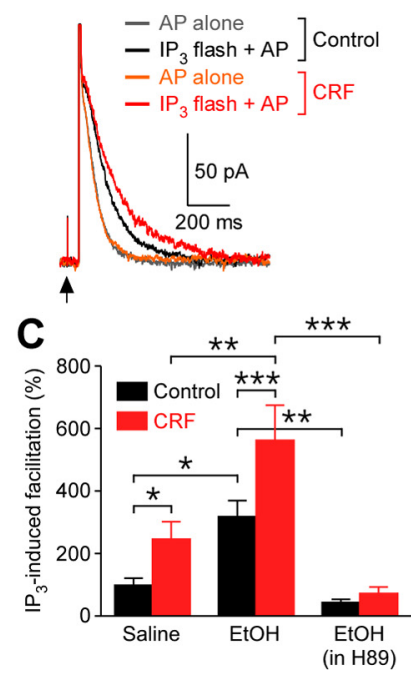

B
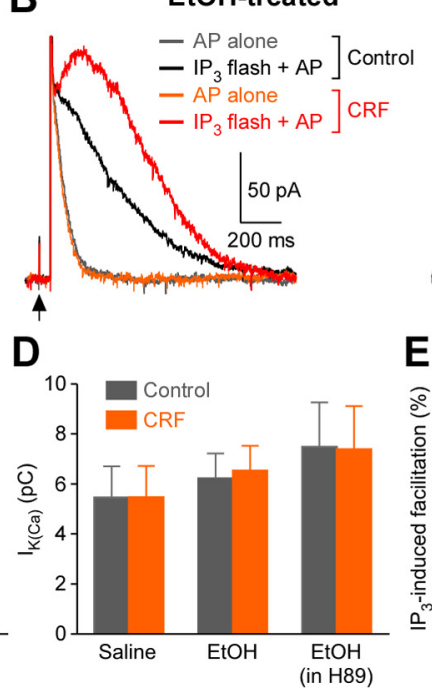
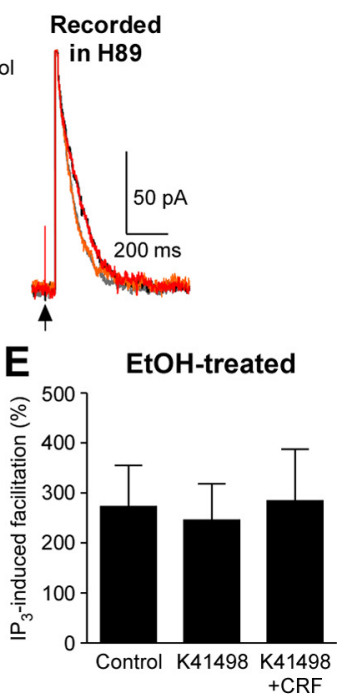

Figure 4. $\quad$ CRF amplifies the increase in $\mathrm{IP}_{3}$ effect on $\mathrm{AP}$-evoked $\mathrm{Ca}^{2+}$ signals produced by in vivo ethanol exposure. $A$, Representative traces of $I_{K\left(C_{a}\right)}$, evoked by itself (gray and orange traces) or paired with preceding photolysis of caged $\mathrm{IP}_{3}(25 \mu \mathrm{M}$; black and red traces), in a saline-treated mouse. A low-intensity UV flash (100 $\mu \mathrm{F}$ ) was applied at the arrow ( $50 \mathrm{~ms}$ before the AP). The magnitude of $\mathrm{IP}_{3}$-induced facilitation of $I_{\mathrm{K}(\mathrm{Ca})}$ is determined by comparing gray and black traces in control solution and by comparing orange and red traces in CRF $(300 \mathrm{nM})$. Note that bath perfusion of CRF, which failed to affect $I_{\mathrm{K}(\mathrm{Ca})}$ itself, was capable of augmenting $\mathbb{I P}_{3}$-induced facilitation. $\boldsymbol{B}$, Representative traces of $I_{K\left(C_{\mathrm{C}}\right)}$, evoked as in $\boldsymbol{A}$, from an ethanol-treated mouse. $\mathbb{I}_{3}$ produced robust facilitation of $I_{\mathrm{K}(\mathrm{Ca})}$ (black trace), which was further augmented by CRF (red trace). Treatment with $\mathrm{H} 89(10 \mu \mathrm{M})$ largely suppressed $\mathrm{IP}_{3}$-induced $I_{\mathrm{K}(\mathrm{Ca})}$ facilitation and abolished the CRF effect. C, Summary bar graph plotting the magnitude of $\mathbb{I P}_{3}$-induced facilitation of $I_{\mathrm{K}(\mathrm{Ca})}$ under the conditions illustrated in $\boldsymbol{A}$ and $\boldsymbol{B}$ (saline group, 8 cells from 4 mice; ethanol group, 6 cells from 4 mice; ethanol group recorded in H89: 6 cells from 5 mice; group: $F_{(2,17)}=11.4, p<0.001 ;$ (RF: $F_{(1,17)}=21.1, p<0.001$; group $\times$ CRF: $F_{(2,17)}=4.38, p<0.05$, mixed two-way ANOVA). ${ }^{*} p<0.05$, ${ }^{* *} p<0.01,{ }^{* * *} p<0.001$. D, Summary bar graph depicting the size of $I_{K(\mathrm{Ca})}$ (without $\mathrm{IP}_{3}$ ). These data were from the same cells shown in $C$. $E$, The $\mathrm{CRF}_{2}$ receptor antagonist $K 41498$ blocked the augmentation of $\mathrm{IP}_{3}$-induced facilitation of $I_{\mathrm{K}(\mathrm{Ca})}$ by $\mathrm{CRF}$ ( 5 cells from 3 ethanol-treated mice).

vides an important insight into the neural plasticity mediating the learning component of alcoholism.

\section{Repeated ethanol exposure enhances $\mathrm{IP}_{3} \mathrm{R}$ sensitivity}

The increase in $\mathrm{IP}_{3}$-induced $\mathrm{Ca}^{2+}$ signaling observed in ethanoltreated mice is most likely due to increased PKA phosphorylation of $\mathrm{IP}_{3} \mathrm{Rs}$, as it can be mimicked by activation of the cAMP/PKA pathway by forskolin and reversed by the PKA inhibitor H89. Changes in gene expression and protein levels of multiple components of the cAMP/PKA pathway have been found in tissue samples from human alcoholic brain (Yamamoto et al., 2001; Mayfield et al., 2002). Furthermore, upregulation of the cAMP/ PKA pathway, presumably resulting from chronic activation of $\mathrm{G}_{\mathrm{i}}$-coupled receptors, such as $\mathrm{D}_{2}$ dopamine receptors or $\mu$-opioid receptors, appears to be a common neuroadaptation observed in the mesolimbic system and other brain areas following exposure to different drugs of abuse (Hyman et al., 2006). Indeed, ethanol is known to elevate dopamine levels within the VTA, activating $\mathrm{D}_{2}$ autoreceptors on dopamine neurons (Yan et al., 1996; Kohl et al., 1998). Ethanol-induced dopamine release in the VTA has also been shown to activate presynaptic $D_{1}$ receptors on glutamatergic terminals, which may further increase somatodendritic dopamine release via glutamatergic excitation of dopamine neurons (Deng et al., 2009; Xiao et al., 2009). Furthermore, we have recently reported a similar PKA-dependent increase in $\mathrm{IP}_{3} \mathrm{R}$ sensitivity in dopamine neurons following in vivo exposure to amphetamine (Ahn et al., 2010). Thus, repetitive stimulation of $\mathrm{D}_{2}$ autoreceptors as a consequence of drug-induced dopamine release within the VTA may be a potential mechanism mediating the enhancement of $\mathrm{IP}_{3} \mathrm{R}$ function.
The basal $I_{\mathrm{K}(\mathrm{Ca})}$ was not altered by repeated ethanol exposure or by modulation of the cAMP/PKA pathway with forskolin or H89, suggesting that PKA does not significantly affect voltage-gated $\mathrm{Ca}^{2+}$ channels responsible for $\mathrm{AP}$-induced $\mathrm{Ca}^{2+}$ influx. PKA-mediated phosphorylation is known to modulate multiple types of voltage-gated $\mathrm{Ca}^{2+}$ channels (Hell et al., 1995; Dolphin, 1996), including L-type $\mathrm{Ca}^{2+}$ channels that are highly expressed in dopamine neurons and play an important role in AP firing ( $\mathrm{Ra}-$ jadhyaksha et al., 2004; Chan et al., 2007). However, PKA sensitivity of the poreforming $\alpha_{1}$ subunit of L-type channels appears to be determined by alternative splicing and the presence of certain auxiliary subunits (Hell et al., 1993; Liang and Tavalin, 2007). To our knowledge, the precise splice variant and subunit composition of L-type channels in dopamine neurons are unknown.

\section{Interactions between the CRF system} and ethanol-induced neuroadaptations An extensive body of work has implicated stress and the CRF system in the acquisition, expression, and reinstatement of drug-seeking behaviors (Sarnyai et al., 2001; Heilig and Koob, 2007). For example, stress-induced enhancement of the acquisition of cocaine CPP can be reversed by systemic administration of a CRF receptor antagonist (Kreibich et al., 2009). Furthermore, acute stress has been shown to more effectively increase opiate self-administration when the stressor and the self-administration session are closely paired in time and not when the stressor is applied several hours after the end of the session, suggesting that stress can strengthen learned associations that contribute to drug taking behavior (Shaham, 1993). Recent evidence also indicates direct interactions between CRF and dopamine systems within the VTA. Indeed, stress-induced CRF release in the VTA can trigger reinstatement of cocaine-seeking behavior (Wise and Morales, 2010), which could be mediated by direct effects of CRF on intrinsic excitability or glutamatergic excitation of dopamine neurons (Ungless et al., 2003; Wanat et al., 2008). Our finding that CRF potentiates $\mathrm{IP}_{3}$-induced facilitation of $I_{\mathrm{K}(\mathrm{Ca})}$ is in agreement with a previous study demonstrating that CRF increases mGluR-mediated intracellular $\mathrm{Ca}^{2+}$ release in dopamine neurons (Riegel and Williams, 2008). These CRF effects on $\mathrm{Ca}^{2+}$ signaling occur via the cAMP/PKA pathway, which also mediates the effects of repeated in vivo exposure to ethanol and amphetamine, as described above. Despite this shared mechanism of action, the enhancement of $\mathrm{IP}_{3}$ sensitivity by ethanol exposure does not occlude the facilitation of AP-evoked $\mathrm{Ca}^{2+}$ signals by CRF. On the contrary, a robust facilitation of $\mathrm{IP}_{3}$-mediated $\mathrm{Ca}^{2+}$ release can be achieved when acute $\mathrm{CRF}$ is combined with prior ethanol exposure. PKA regulation of $\mathrm{IP}_{3}$ Rs may, therefore, represent an important site of convergence where the stress system interacts with drug-induced neuroadaptations, thereby promoting drug-induced learning and behaviors. In this regard, it should be noted that increased CRF levels are observed during ethanol withdrawal in multiple brain areas of rodents (Sarnyai et al., 

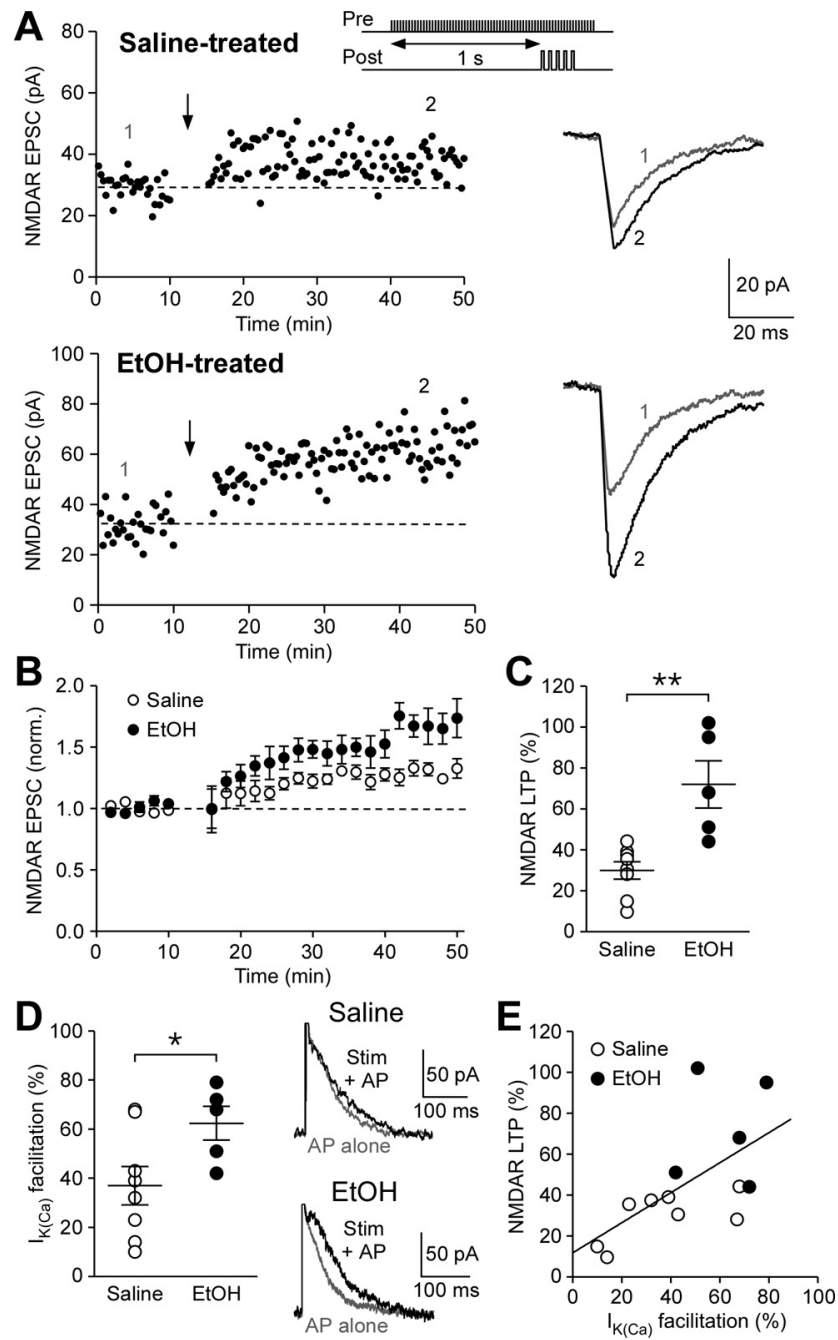

Figure 5. NMDAR-mediated transmission becomes more susceptible to LTP induction after repeated ethanol exposure. $\boldsymbol{A}$, Example experiments to induce NMDAR LTP in saline- and ethanol-treated mice. Time graphs of NMDAR EPSC amplitude are shown on the left. The LTP induction protocol, which consisted of synaptic stimulation-burst pairing (top inset), was delivered at the time indicated by the arrow. Traces of NMDAR EPSCs at times indicated by numbers in the time graphs are shown on the right. $\boldsymbol{B}$, Summary time graph of NMDAR LTP experiments (saline group, 8 cells from 7 mice; ethanol group, 5 cells from 5 mice). C, Summary graph plotting the magnitude of NMDAR LTP in saline- and ethanol-treated mice $\left(t_{11}=4.04\right.$, $p<0.01$, unpaired $t$ test). $D$, Summary graph showing that the magnitude of $I_{\mathrm{K}(\mathrm{Ca})}$ facilitation produced by preceding synaptic stimulation was larger in ethanol-treated mice $\left(t_{11}=2.25\right.$, $p<0.05$, unpaired $t$ test). Example traces illustrating synaptic facilitation of $I_{\mathrm{K}(\mathrm{Ca})}$ are shown on the right. $\boldsymbol{E}$, The magnitude of NMDAR LTP is plotted versus the magnitude of synaptic facilitation of $I_{K\left(C_{a}\right)}$ in the cells shown in. Solid line is a linear fit to all data points from both saline- and ethanol-treated mice. The data summarized in $\boldsymbol{B}-\boldsymbol{E}$ were all from the same cells.

2001; Heilig and Koob, 2007) as well as in the CSF of alcoholdependent humans (Adinoff et al., 1996). Thus, although CRF tone was not detected in VTA slices in the present study, VTA CRF levels may be elevated in vivo during ethanol withdrawal.

Previous studies have found that CRF can activate the phospholipase C (PLC) pathway in dopamine neurons (Ungless et al., 2003; Wanat et al., 2008). Since PLC activation leads to the generation of $\mathrm{IP}_{3}$, CRF could be expected to facilitate $I_{\mathrm{K}(\mathrm{Ca})}$ itself through this pathway, as agonists of mGluRs and other PLCcoupled receptors do (Cui et al., 2007). However, CRF failed to facilitate $I_{\mathrm{K}(\mathrm{Ca})}$ unless APs were combined with preceding $\mathrm{IP}_{3}$ flash photolysis in the present study. This result suggests that coupling of CRF receptors to the PLC pathway may not be strong
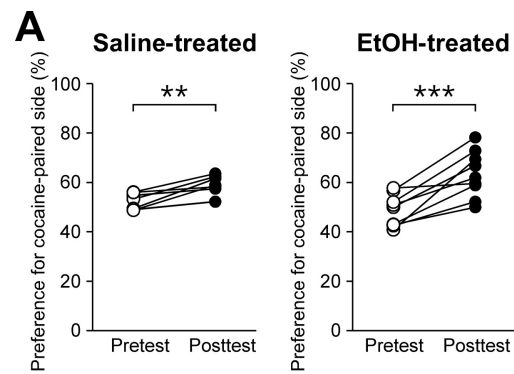

B
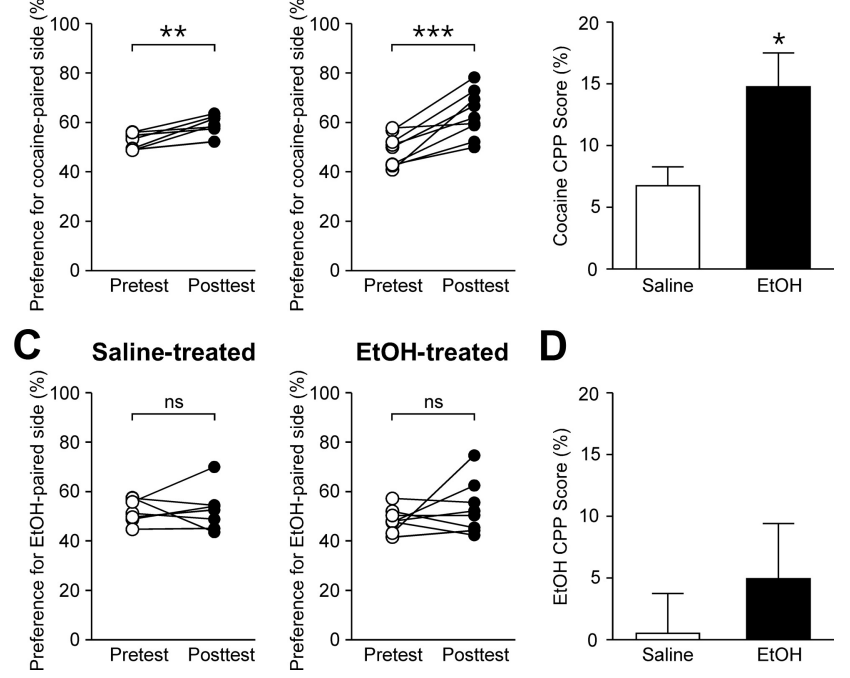

D

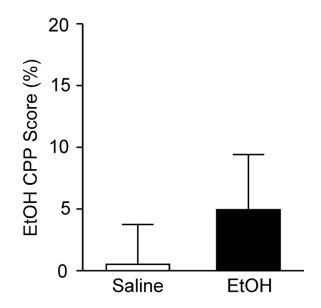

Figure 6. Previous ethanol exposure promotes cocaine-induced CPP. A, Changes in the preference for the cocaine-paired side after $2 \mathrm{~d}$ conditioning are shown for saline- and ethanoltreated mice (saline group, $t_{6}=4.46, p<0.01$; ethanol group, $t_{8}=5.39, p<0.001$, paired $t$ test). $\boldsymbol{B}$, Summary bar graph showing that cocaine (PP is enhanced in ethanol-treated mice $\left(t_{14}=2.35, p<0.05\right.$, unpaired $t$ test). $C$, Changes in the preference for the ethanol-paired side after $4 \mathrm{~d}$ conditioning are shown for saline- and ethanol-treated mice (saline group, $t_{6}=0.16$, $p=0.88$; ethanol group, $t_{7}=1.10, p=0.31$, paired $t$ test). $\boldsymbol{D}$, Summary bar graph of ethanol CPP experiments $\left(t_{13}=0.78, p=0.45\right.$, unpaired $t$ test $)$.

enough to produce a sufficient amount of $\mathrm{IP}_{3}$ to cause $I_{\mathrm{K}(\mathrm{Ca})}$ facilitation by itself.

\section{Repeated ethanol exposure enhances NMDAR plasticity and} learning of drug-associated stimuli

Extensive studies have shown that in vivo exposure to drugs of abuse, including ethanol, causes global potentiation of AMPAR, but not NMDAR, function in VTA dopamine neurons (Brodie, 2002; Saal et al., 2003; Hopf et al., 2007; Kauer and Malenka, 2007; Stuber et al., 2008). This generalized increase in the sensitivity of dopamine neurons to AMPAR-mediated excitation is thought to result in increased dopamine release in the nucleus accumbens and other dopamine neuron projection areas, thereby enhancing activity-dependent synaptic plasticity in those areas (Wolf et al., 2004). In contrast, the present study demonstrates that ethanol exposure induces neuroadaptation within the VTA that facilitates activity-dependent plasticity of NMDARmediated glutamatergic transmission onto dopamine neurons, as has been shown previously with amphetamine exposure (Ahn et al., 2010). NMDARs are thought to play a critical role in triggering phasic dopamine neuron responses to reward-predicting cues (Sombers et al., 2009; Zweifel et al., 2009). Interestingly, in vivo exposure to ethanol and other drugs of abuse has been shown to impair LTP induction at GABAergic synapses in VTA dopamine neurons (Guan and Ye, 2010; Niehaus et al., 2010; but also see Melis et al., 2002). Since GABAergic inhibition can effectively suppress NMDAR-induced burst firing (Lobb et al., 2010), these two forms of metaplasticity, i.e., enhancement of NMDAR LTP and impairment of GABA LTP, may work in concert to promote the development of conditioned dopamine neuron responses to environmental stimuli associated with drug experience.

NMDAR activation in the VTA is required for the learning of drug-associated cues assessed with a CPP paradigm (Harris et al., 2004; Zweifel et al., 2008). In accordance with this idea, acute 
ethanol exposure, which inhibits NMDARs (Lovinger et al., 1989), has been shown to interfere with CPP when administered immediately before conditioning sessions (Cunningham and Gremel, 2006). In contrast, our CPP experiments show that the same repeated ethanol treatment that enhances NMDAR LTP also enhances subsequent learning of cocaine-associated cues. Previous studies performing long-term ethanol preexposure did not find an enhancement of cocaine or ethanol CPP (Le Pen et al., 1998; Busse et al., 2005). However, these studies both used significantly different ethanol treatment protocols than the one used here, involving much fewer ethanol injections or drinking of ethanol-containing solutions. These discrepancies suggest that fewer doses or more gradual intake of ethanol may not be sufficient to induce the neuroadaptations underlying the enhanced CPP seen in the present study. This type of "cross-sensitization" of learning shown in our study has been demonstrated with other drugs of abuse using CPP or operant conditioning paradigms (Lett, 1989; Horger et al., 1992), which may account for the concurrent use of different types of drugs frequently seen in alcoholics and drug addicts (Pennings et al., 2002; Dani and Harris, 2005). Sensitization of $\mathrm{IP}_{3}$ Rs in the VTA may thus be a common drug-induced neuroadaptation among alcohol and other drugs of abuse that acts to drive the formation of powerful memories of stimuli encountered during the initial days to weeks of drug experience and withdrawal.

\section{References}

Adinoff B, Anton R, Linnoila M, Guidotti A, Nemeroff CB, Bissette G (1996) CSF concentrations of corticotropin-releasing hormone (CRH) and diazepam-binding inhibitor (DBI) during alcohol withdrawal and abstinence. Neuropsychopharmacology 15:288-295.

Ahn KC, Bernier BE, Harnett MT, Morikawa H (2010) IP3 receptor sensitization during in vivo amphetamine experience enhances NMDA receptor plasticity in dopamine neurons of the ventral tegmental area. J Neurosci 30:6689-6699.

Belmeguenai A, Botta P, Weber JT, Carta M, De Ruiter M, De Zeeuw CI, Valenzuela CF, Hansel C (2008) Alcohol impairs long-term depression at the cerebellar parallel fiber-Purkinje cell synapse. J Neurophysiol 100:3167-3174.

Blednov YA, Metten P, Finn DA, Rhodes JS, Bergeson SE, Harris RA, Crabbe JC (2005) Hybrid C57BL/6J $\times$ FVB/NJ mice drink more alcohol than do C57BL/6J mice. Alcohol Clin Exp Res 29:1949-1958.

Brodie MS (2002) Increased ethanol excitation of dopaminergic neurons of the ventral tegmental area after chronic ethanol treatment. Alcohol Clin Exp Res 26:1024-1030.

Busse GD, Lawrence ET, Riley AL (2004) The modulation of cocaineinduced conditioned place preferences by alcohol: effects of cocaine dose. Prog Neuropsychopharmacol Biol Psychiatry 28:149-155.

Busse GD, Lawrence ET, Riley AL (2005) The effects of alcohol preexposure on cocaine, alcohol and cocaine/alcohol place conditioning. Pharmacol Biochem Behav 81:459-465.

Chan CS, Guzman JN, Ilijic E, Mercer JN, Rick C, Tkatch T, Meredith GE, Surmeier DJ (2007) 'Rejuvenation' protects neurons in mouse models of Parkinson's disease. Nature 447:1081-1086.

Crabbe JC, Cotnam CJ, Cameron AJ, Schlumbohm JP, Rhodes JS, Metten P, Wahlsten D (2003) Strain differences in three measures of ethanol intoxication in mice: the screen, dowel and grip strength tests. Genes Brain Behav 2:201-213.

Cui G, Bernier BE, Harnett MT, Morikawa H (2007) Differential regulation of action potential- and metabotropic glutamate receptor-induced $\mathrm{Ca}^{2+}$ signals by inositol 1,4,5-trisphosphate in dopaminergic neurons. J Neurosci 27:4776-4785.

Cunningham CL, Gremel CM (2006) Proximal ethanol pretreatment interferes with acquisition of ethanol-induced conditioned place preference. Pharmacol Biochem Behav 85:612-619.

Cunningham CL, Niehus DR, Malott DH, Prather LK (1992) Genetic differences in the rewarding and activating effects of morphine and ethanol. Psychopharmacology (Berl) 107:385-393.
Dani JA, Harris RA (2005) Nicotine addiction and comorbidity with alcohol abuse and mental illness. Nat Neurosci 8:1465-1470.

Deng C, Li KY, Zhou C, YeJH (2009) Ethanol enhances glutamate transmission by retrograde dopamine signaling in a postsynaptic neuron/synaptic bouton preparation from the ventral tegmental area. Neuropsychopharmacology 34:1233-1244.

Dolphin AC (1996) Facilitation of $\mathrm{Ca}^{2+}$ current in excitable cells. Trends Neurosci 19:35-43.

Elmer GI, Meisch RA, George FR (1987) Differential concentrationresponse curves for oral ethanol self-administration in C57BL/6J and BALB/cJ mice. Alcohol 4:63-68.

Guan YZ, Ye JH (2010) Ethanol blocks long-term potentiation of GABAergic synapses in the ventral tegmental area involving mu-opioid receptors. Neuropsychopharmacology 35:1841-1849.

Guatteo E, Mercuri NB, Bernardi G, Knöpfel T (1999) Group I metabotropic glutamate receptors mediate an inward current in rat substantia nigra dopamine neurons that is independent from calcium mobilization. J Neurophysiol 82:1974-1981.

Harnett MT, Bernier BE, Ahn KC, Morikawa H (2009) Burst-timingdependent plasticity of NMDA receptor-mediated transmission in midbrain dopamine neurons. Neuron 62:826-838.

Harris GC, Wimmer M, Byrne R, Aston-Jones G (2004) Glutamate-associated plasticity in the ventral tegmental area is necessary for conditioning environmental stimuli with morphine. Neuroscience 129:841-847.

Heilig M, Koob GF (2007) A key role for corticotropin-releasing factor in alcohol dependence. Trends Neurosci 30:399-406.

Hell JW, Yokoyama CT, Wong ST, Warner C, Snutch TP, Catterall WA (1993) Differential phosphorylation of two size forms of the neuronal class C L-type calcium channel alpha 1 subunit. J Biol Chem 268:19451-19457.

Hell JW, Yokoyama CT, Breeze LJ, Chavkin C, Catterall WA (1995) Phosphorylation of presynaptic and postsynaptic calcium channels by cAMPdependent protein kinase in hippocampal neurons. EMBO J 14:3036-3044.

Hopf FW, Martin M, Chen BT, Bowers MS, Mohamedi MM, Bonci A (2007) Withdrawal from intermittent ethanol exposure increases probability of burst firing in VTA neurons in vitro. J Neurophysiol 98:2297-2310.

Horger BA, Giles MK, Schenk S (1992) Preexposure to amphetamine and nicotine predisposes rats to self-administer a low dose of cocaine. Psychopharmacology (Berl) 107:271-276.

Hyman SE, Malenka RC, Nestler EJ (2006) Neural mechanisms of addiction: the role of reward-related learning and memory. Annu Rev Neurosci 29:565-598.

Kauer JA, Malenka RC (2007) Synaptic plasticity and addiction. Nat Rev Neurosci 8:844-858.

Kohl RR, Katner JS, Chernet E, McBride WJ (1998) Ethanol and negative feedback regulation of mesolimbic dopamine release in rats. Psychopharmacology (Berl) 139:79-85.

Kreibich AS, Briand L, Cleck JN, Ecke L, Rice KC, Blendy JA (2009) Stressinduced potentiation of cocaine reward: a role for CRF R1 and CREB. Neuropsychopharmacology 34:2609-2617.

Le Pen G, Duterte-Boucher D, Daoust M, Costentin J (1998) Pre-exposure to alcohol does not sensitize to the rewarding effects of cocaine. Neuroreport 9:2887-2891.

Lett BT (1989) Repeated exposures intensify rather than diminish the rewarding effects of amphetamine, morphine, and cocaine. Psychopharmacology (Berl) 98:357-362.

Liang Y, Tavalin SJ (2007) Auxiliary beta subunits differentially determine pka utilization of distinct regulatory sites on Cav1.3 $\mathrm{L}$ type $\mathrm{Ca}^{2+}$ channels. Channels (Austin) 1:102-112.

Lobb CJ, Wilson CJ, Paladini CA (2010) A dynamic role for GABA receptors on the firing pattern of midbrain dopaminergic neurons. J Neurophysiol 104:403-413.

Lovinger DM, White G, Weight FF (1989) Ethanol inhibits NMDAactivated ion current in hippocampal neurons. Science 243:1721-1724.

Mayfield RD, Lewohl JM, Dodd PR, Herlihy A, Liu J, Harris RA (2002) Patterns of gene expression are altered in the frontal and motor cortices of human alcoholics. J Neurochem 81:802-813.

McCray JA, Herbette L, Kihara T, Trentham DR (1980) A new approach to time-resolved studies of ATP-requiring biological systems; laser flash photolysis of caged ATP. Proc Natl Acad Sci U S A 77:7237-7241.

Melis M, Camarini R, Ungless MA, Bonci A (2002) Long-lasting potentiation of GABAergic synapses in dopamine neurons after a single in vivo ethanol exposure. J Neurosci 22:2074-2082. 
Morikawa H, Imani F, Khodakhah K, Williams JT (2000) Inositol 1,4,5triphosphate-evoked responses in midbrain dopamine neurons. J Neurosci $20:$ RC103.

Nelson TE, Ur CL, Gruol DL (2005) Chronic intermittent ethanol exposure enhances NMDA-receptor-mediated synaptic responses and NMDA receptor expression in hippocampal CA1 region. Brain Res 1048:69-79.

Netzeband JG, Schneeloch JR, Trotter C, Caguioa-Aquino JN, Gruol DL (2002) Chronic ethanol treatment and withdrawal alter ACPD-evoked calcium signals in developing Purkinje neurons. Alcohol Clin Exp Res 26:386-393

Niehaus JL, Murali M, Kauer JA (2010) Drugs of abuse and stress impair LTP at inhibitory synapses in the ventral tegmental area. Eur J Neurosci 32:108-117.

Nomura T, Higashi K, Hoshino M, Saso K, Itou M, Hoek JB (1996) Effect of glutathione on inositol 1,4,5-triphosphate-induced $\mathrm{Ca}^{2+}$ release in permeabilized hepatocytes from control and chronic ethanol-fed rats. Alcohol Clin Exp Res 20:325A-329A.

Ortiz J, Fitzgerald LW, Charlton M, Lane S, Trevisan L, Guitart X, Shoemaker W, Duman RS, Nestler EJ (1995) Biochemical actions of chronic ethanol exposure in the mesolimbic dopamine system. Synapse 21:289-298.

Pennings EJ, Leccese AP, Wolff FA (2002) Effects of concurrent use of alcohol and cocaine. Addiction 97:773-783.

Rajadhyaksha A, Husson I, Satpute SS, Küppenbender KD, Ren JQ, Guerriero RM, Standaert DG, Kosofsky BE (2004) L-type $\mathrm{Ca}^{2+}$ channels mediate adaptation of extracellular signal-regulated kinase $1 / 2$ phosphorylation in the ventral tegmental area after chronic amphetamine treatment. J Neurosci 24:7464-7476.

Rhodes JS, Best K, Belknap JK, Finn DA, Crabbe JC (2005) Evaluation of a simple model of ethanol drinking to intoxication in C57BL/6J mice. Physiol Behav 84:53-63.

Riegel AC, Williams JT (2008) CRF facilitates calcium release from intracellular stores in midbrain dopamine neurons. Neuron 57:559-570.

Roberto M, Bajo M, Crawford E, Madamba SG, Siggins GR (2006) Chronic ethanol exposure and protracted abstinence alter NMDA receptors in central amygdala. Neuropsychopharmacology 31:988-996.

Ron D (2004) Signaling cascades regulating NMDA receptor sensitivity to ethanol. Neuroscientist 10:325-336.

Ryabinin AE (1998) Role of hippocampus in alcohol-induced memory impairment: implications from behavioral and immediate early gene studies. Psychopharmacology (Berl) 139:34-43.

Ryback RS (1971) The continuum and specificity of the effects of alcohol on memory. A review. Q J Stud Alcohol 32:995-1016.

Saal D, Dong Y, Bonci A, Malenka RC (2003) Drugs of abuse and stress trigger a common synaptic adaptation in dopamine neurons. Neuron 37:577-582.

Sabeti J, Gruol DL (2008) Emergence of NMDAR-independent long-term potentiation at hippocampal CA1 synapses following early adolescent exposure to chronic intermittent ethanol: role for sigma-receptors. Hippocampus 18:148-168.

Sarnyai Z, Shaham Y, Heinrichs SC (2001) The role of corticotropinreleasing factor in drug addiction. Pharmacol Rev 53:209-243.

Saso K, Moehren G, Higashi K, Hoek JB (1997) Differential inhibition of epidermal growth factor signaling pathways in rat hepatocytes by longterm ethanol treatment. Gastroenterology 112:2073-2088.

Schultz W (1998) Predictive reward signal of dopamine neurons. J Neurophysiol 80:1-27.

Shaham Y (1993) Immobilization stress-induced oral opioid selfadministration and withdrawal in rats: role of conditioning factors and the effect of stress on "relapse" to opioid drugs. Psychopharmacology (Berl) 111:477-485.
Sombers LA, Beyene M, Carelli RM, Wightman RM (2009) Synaptic overflow of dopamine in the nucleus accumbens arises from neuronal activity in the ventral tegmental area. J Neurosci 29:1735-1742.

Stephens DN, Ripley TL, Borlikova G, Schubert M, Albrecht D, Hogarth L, Duka T (2005) Repeated ethanol exposure and withdrawal impairs human fear conditioning and depresses long-term potentiation in rat amygdala and hippocampus. Biol Psychiatry 58:392-400.

Stuber GD, Hopf FW, Hahn J, Cho SL, Guillory A, Bonci A (2008) Voluntary ethanol intake enhances excitatory synaptic strength in the ventral tegmental area. Alcohol Clin Exp Res 32:1714-1720.

Tozzi A, Bengtson CP, Longone P, Carignani C, Fusco FR, Bernardi G, Mercuri NB (2003) Involvement of transient receptor potential-like channels in responses to mGluR-I activation in midbrain dopamine neurons. Eur J Neurosci 18:2133-2145.

Ungless MA, Singh V, Crowder TL, Yaka R, Ron D, Bonci A (2003) Corticotropin-releasing factor requires $\mathrm{CRF}$ binding protein to potentiate NMDA receptors via CRF receptor 2 in dopamine neurons. Neuron 39:401-407.

Wagner LE 2nd, Joseph SK, Yule DI (2008) Regulation of single inositol 1,4,5-trisphosphate receptor channel activity by protein kinase A phosphorylation. J Physiol 586:3577-3596.

Wanat MJ, Hopf FW, Stuber GD, Phillips PE, Bonci A (2008) Corticotropinreleasing factor increases mouse ventral tegmental area dopamine neuron firing through a protein kinase C-dependent enhancement of Ih. J Physiol 586:2157-2170

Wang J, Lanfranco MF, Gibb SL, Yowell QV, Carnicella S, Ron D (2010) Long-lasting adaptations of the NR2B-containing NMDA receptors in the dorsomedial striatum play a crucial role in alcohol consumption and relapse. J Neurosci 30:10187-10198.

Wise RA, Morales M (2010) A ventral tegmental CRF-glutamate-dopamine interaction in addiction. Brain Res 1314:38-43.

Wolf ME, Sun X, Mangiavacchi S, Chao SZ (2004) Psychomotor stimulants and neuronal plasticity. Neuropharmacology 47 [Suppl 1]:61-79.

Xia JX, Li J, Zhou R, Zhang XH, Ge YB, Ru Yuan X (2006) Alterations of rat corticostriatal synaptic plasticity after chronic ethanol exposure and withdrawal. Alcohol Clin Exp Res 30:819-824.

Xiao C, Shao XM, Olive MF, Griffin WC 3rd, Li KY, Krnjević K, Zhou C, Ye JH (2009) Ethanol facilitates glutamatergic transmission to dopamine neurons in the ventral tegmental area. Neuropsychopharmacology 34:307-318

Xie GQ, Wang SJ, Li J, Cui SZ, Zhou R, Chen L, Yuan XR (2009) Ethanol attenuates the HFS-induced, ERK-mediated LTP in a dose-dependent manner in rat striatum. Alcohol Clin Exp Res 33:121-128.

Yamamoto M, Pohli S, Durany N, Ozawa H, Saito T, Boissl KW, Zöchling R, Riederer P, Böning J, Götz ME (2001) Increased levels of calciumsensitive adenylyl cyclase subtypes in the limbic system of alcoholics: evidence for a specific role of cAMP signaling in the human addictive brain. Brain Res 895:233-237.

Yan QS, Reith ME, Jobe PC, Dailey JW (1996) Focal ethanol elevates extracellular dopamine and serotonin concentrations in the rat ventral tegmental area. Eur J Pharmacol 301:49-57.

Zweifel LS, Argilli E, Bonci A, Palmiter RD (2008) Role of NMDA receptors in dopamine neurons for plasticity and addictive behaviors. Neuron 59:486-496.

Zweifel LS, Parker JG, Lobb CJ, Rainwater A, Wall VZ, Fadok JP, Darvas M, Kim MJ, Mizumori SJ, Paladini CA, Phillips PE, Palmiter RD (2009) Disruption of NMDAR-dependent burst firing by dopamine neurons provides selective assessment of phasic dopamine-dependent behavior. Proc Natl Acad Sci U S A 106:7281-7288. 